\title{
Review on Islamic Corporate Real Estate Sustainable Management (I-Cresm) Practice
}

Nurul Sahida Fauzi, Ashrof Zainuddin, Nor Nazihah Chuweni, Noraini Johari, Abdul Hadi Nawawi

To Link this Article: http://dx.doi.org/10.6007/IJARBSS/v11-i1/9013

DOI:10.6007/IJARBSS/v11-i1/9013

Received: 02 November 2020, Revised: 03 December 2020, Accepted: 14 January 2021

Published Online: 26 January 2021

In-Text Citation: (Fauzi et al., 2021)

To Cite this Article: Fauzi, N. S., Zainuddin, A., Chuweni, N. N., Johari, N., \& Nawawi, A. H. (2021). Review on Islamic Corporate Real Estate Sustainable Management (I-Cresm) Practice. International Journal of Academic Research in Business and Social Sciences, 11(1), 896-902.

Copyright: (c) 2021 The Author(s)

Published by Human Resource Management Academic Research Society (www.hrmars.com)

This article is published under the Creative Commons Attribution (CC BY 4.0) license. Anyone may reproduce, distribute, translate and create derivative works of this article (for both commercial and non-commercial purposes), subject to full attribution to the original publication and authors. The full terms of this license may be seen at: http://creativecommons.org/licences/by/4.0/legalcode

Vol. 11, No. 1, 2021, Pg. 896 - 902

Full Terms \& Conditions of access and use can be found at http://hrmars.com/index.php/pages/detail/publication-ethics 


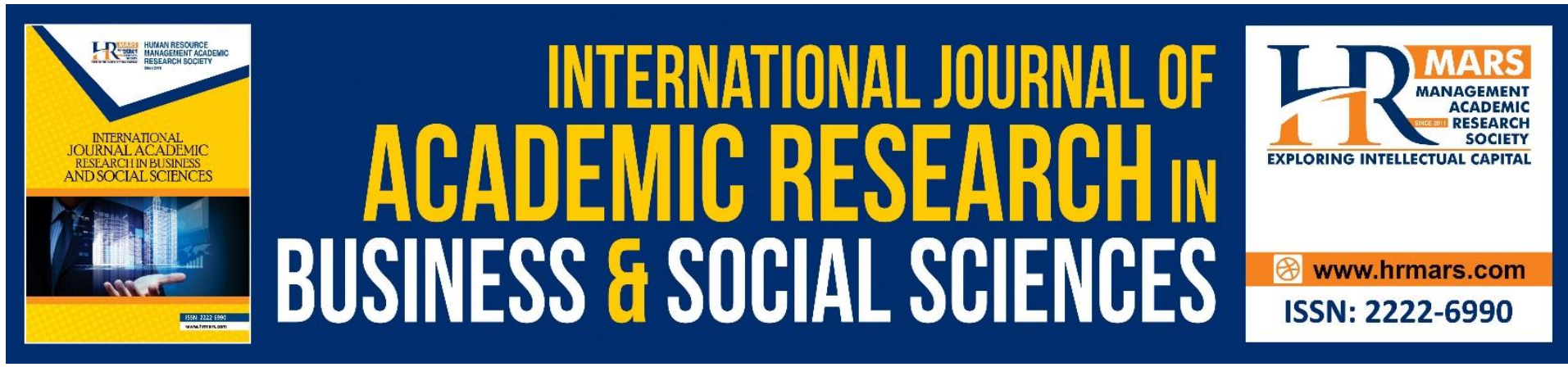

\title{
Review on Islamic Corporate Real Estate Sustainable Management (I-Cresm) Practice
}

\author{
Nurul Sahida Fauzi ${ }^{1}$, Ashrof Zainuddin ${ }^{1}$, Nor Nazihah \\ Chuweni ${ }^{1}$, Noraini Johari ${ }^{1}$, Abdul Hadi Nawawi ${ }^{2}$ \\ ${ }^{1}$ Department of Estate Management, Faculty of Architecture, Planning and Surveying, \\ Universiti Teknologi MARA, Perak Branch, Seri Iskandar Campus, Seri Iskandar, 32610 Perak, \\ Malaysia, ${ }^{2}$ Department of Estate Management, Faculty of Architecture, Planning and \\ Surveying, Universiti Teknologi MARA, Shah Alam, 40450 Shah Alam, Malaysia
}

\begin{abstract}
Islam views humans as God's stewards on earth in preserving the environment in order to avoid dire circumstances. Therefore, the concept of preserving the resources for future generations or sustainability has been exposed to all Muslims. Various versus in Qur'an and Sunnah of the Prophet Muhammad S.A.W highlight the roles and responsibilities of man as a Khalifatullah (the vicegerent of Allah) to preserve the environment; and prohibit mischief to the earth. Global warming and climate change due to human actions have contributed towards many disasters particularly involving the real estate industry. Hence, sustainable practices are found to benefit not only the environment but have contributed to the positive wave of social developments and economic strength. This study attempts to explore the Islamic sustainable principles for corporate real estate management (CREM) practice. Previous writings on Islamic perspective for real estate management were reviewed and references made to the revealed sources of Al-Qur'an, and the Sunnah of Prophet Muhammad S.A.W. Results indicate eight principles of sustainable practices for CREM including sustainable utilization of water, organizational management and good governance, human satisfaction, environmental protection, waste management, energy management, innovation and work-space management. It then suggests further investigation to be conducted involving current practices by CRE managers to gather more relevant and accurate data.
\end{abstract}

Keywords: Corporate Real Estate Sustainable Management, Islamic Principle

\section{Introduction}

The revolution towards sustainability started when the world became concerned with the issues of global warming and climate change that affected negatively on life as we know it. Warren-myers (2012) identified that sustainability concerns surfaced in 1987 due to the scarcity of the world's resources and high carbon emission levels that contributed to global warming and climate change. Additionally, Samad et al. (2010) recorded that the building sector consumes about 40 percent of energy, 12 percent of water and contributes 40 percent 
of waste. Similarly, N. S. Fauzi et al. (2016) realized that global warming issues have motivated most corporations to integrate sustainable concepts into their business services and operations. In fact in the Islamic traditions, sustainable issues have been educated to all Muslims from a very long time ago as stated in a plethora of versus in the Qur'an and several sayings of the Prophet Muhammad S.A.W. These traditions preach on the roles and responsibilities of man as Khalifatullah (the vicegerent of Allah) on earth to care for and preserve the environment; and prohibit man to do mischief on earth. Unfortunately, today many disasters happened because of human actions. A case in point is the property industry where research revealed that this industry contributed to the negative impact on the environment starting from the construction period until the completion time. Furthermore, most buildings contribute to the carbon emissions and other contaminants throughout their life cycles (N. S. Fauzi et al., 2016). Umar \& Khamidi (2012) concurred that buildings contribute to about $38 \%$ of the carbon emissions. Carbon emission from the building materials is capable of increasing the air temperature thus warming up the Earth's atmosphere (Umar \&Khamidi, 2012). Hence, today most of the real estate developments are encouraged to apply sustainable real estate development practices to mitigate these issues. Similarly in the corporate real estate management practice where sustainable elements are adopted due to the continually increasing numbers of green corporate real estate (CRE). However, we find very few discussions on sustainable practices. Fauzi et al. (2017) reported that sustainable real estate concepts are still at an early stage of awareness. Therefore, this study was conducted to identify sustainable elements that are embedded in contemporary corporate real estate management practices.

\section{Islamic Principes of Sustainable Practice for Crem}

CRE refers to the lands and buildings owned by corporations that are not primarily involved in the real estate business (Musa \& Ahmad @ Baharum, 2012). It includes leasehold real estate that is controlled by the corporation (Abdul Jalil Omar \& Heywood, 2014). Additionally, CRE is also interpreted as corporate property or real estate that covers industries, offices and retail spaces used for business purposes (Nappi-Choulet et al., 2009). While, CRE management that incorporates sustainable elements is known as corporate real estate sustainable management (CRESM) (Fauzi et al., 2016) or sustainable corporate real estate management (SCREM) (Ziemba et al., 2015).

The concept of sustainable development in Islam is known as a balanced and continual enhancement in material and non-material prosperity of man for both here on earth and in the hereafter (Julia, Kassim, \& Ali, 2018). Various viewpoints determine "sustainable" as balancing economic, social and environmental elements through consumer welfare and economic efficiency, realization of social justice, and environmental balance (lyadAbumoghli, 2016). Similarly, the definition of sustainability in general encompasses those actions that recognize renewable resources and ecological capabilities to support human life (Sarkawi et al., 2016). It reflects three objectives namely environmental, economic, and social (Samad et al., 2010). CRESM practices that incorporate the three sustainable pillars of the environment, social, and economic must also be in line with the corporate objectives (Fauzi et al., 2016). The difference between them is in the Islamic practices that are conducted in accordance with the Shariah principles and stressed on moral values (Darus et al., 2013). Julia et al., (2018) agreed and stressed on a common Shariah school of thought "Shariah is life" that shows life cannot be viewed separately from Shariah. 
In Islamic principles, man should appreciate all of the earth's resources and use it considerately and moderately. Besides that, man is responsible to maintain and preserve this gift in order to share the benefits received with the future generation (IyadAbumoghli, 2016). This is in line with Imam Al-Ghazali's view on sustainable objectives that are to preserve lives, posterity and wealth (Julia et al., 2018). IyadAbumoghli (2016) added several Islamic principles for sustainable development, some of which may be suitable for application to CRESM. It includes sustainable utilization of water including its efficient use and its conservation, organizational management, knowledge and education, environmental protection, waste generation, cultural and ethnic values, and responsibility towards the disabled and the poor.

Sustainable utilization of water: Water is a very important resource from the earth as a gift from Allah S.W.T to sustain life. The word "water" occurs sixty six times in several verses of the Qur'an. The Prophet Muhammad S.A.W. also emphasized in his teachings on the proper use of water and avoiding extravagance. He once admonished a sahaba against wastage of water, telling him that even if he were to be washing on the banks of a river, he should not waste water. In addition, water is the life source for living things, without water, crops are unable to grow and humans and animals are unable to thrive (Mohammed et al., 2009). Allah decreed in the Qur'an "We made from water every living thing" (Al-Anbiya', 21:30). Various versus in the Qur'an also stressed on the importance of water such as Al- Nahl :65, Al-Rum :24 and Qaf: 9. Therefore, water is very important to be efficiently used and conserved as compiled by Imam Abu Dawud on various traditions of the Prophet Muhammad (Mohammed et al., 2009) .

Organizational management and good governance: Islamic organizational management places great importance on Shura in the decision-making process. Shura means consultation process. Good governance should be embedded in organizational management. This is to avoid mismanagement and destruction. The Qur'an prohibits man from doing mischief to the earth. Good management practices will seriously take heed of this obligation and avoid any harm to the earth, which includes the environment and all creatures on earth. Mohamad\& Hussein (2018) emphasized on the importance of appointing the right person in managing property. The Prophet Muhammad S.A.W. said, "One who appoints an incompetent person to a responsible post has as though betrayed Allah and the Prophet". Good teamwork is the key to successful achievement of management goals (Mohamad \& Hussein, 2018). Allah commanded in Al-Imran 3:103 that we must hold fast onto the rope which Allah (stretches out for you), and be not divided among yourselves to gain Allah's blessings. In reference to this surah, Julia et al. (2018) propose that illustrious Muslim countries would be able to move forward and be more developed at par with other countries if they implement and practice Islamic sustainable management practices in their lives.

Knowledge and education: The critical elements in order to develop an in-depth understanding on the importance of sustainability and the benefits derived from them. As mentioned earlier, Islam has educated all Muslims on the ethics and guidelines to preserve the environment. Paradoxically, still a lot of negative actions and practices are conducted on a day-to-day basis contributing to the disasters and harm on earth. All these call for more concerted efforts by every stakeholder to counter the ill effects on earth. Corporations will 
do well to respond by investing in knowledge sharing and education in the form of motivation and training of their employees (Julia et al., 2018).

Environmental Protection: This principle aims to balance natural resources and conservation of the environment. It controls uses of biodiversity and implements environmental impact assessment and mitigation. This principle preaches reduction in use of artificial resources that contaminate the atmosphere, the environment and mankind (Julia et al., 2018). The Qur'an advises all Muslim to practice moderation in whatever we do and maintain the balance as Allah has created the world in balance. Going against Allah's decree causes harm to the earth as pointed out in surah Ar Rum 30:41 that mischief has appeared on land and sea because of the hands of man. Islam is also against extremism (Mohamad \& Hussein, 2018) as stated in Al Furqan 77:67. Both the Qur'an and Sunnah provide guidelines on physical and non-physical welfares of humanity and warn against selfish exploitations and excessive use of natural resources (Julia et al., 2018). The fundamental legal principle established by the Prophet Muhammad S.A.W. is that "the benefit of thing is in return for the liability attached to it". Hence, managers should conduct environmental impact assessments to mitigate the worst effects to the earth and all creatures on earth.

Waste Generation: Islamic principles encourage minimizing waste in whatever activities including eating, drinking (Al-A'raf 7:31) and others. Julia et al., (2018) echoed the urgent need to minimize waste. Waste consists of several types such as waste of natural resources, domestic waste, chemical waste, clinical waste and e-waste. Organization of waste is crucial to avoid proliferation of diseases, bad odour and pollution.

Cultural and Ethnic Values: In Islamic principles, cultural and ethnic values present the beauty of racial, spiritual, cultural and ethnic diversities that can create harmony in life. Their basic tenets are outlined in the teachings of Islam and guidelines from the Qur'an and Sunnah.

Responsibilities towards the Disabled and the Poor: These include concern on differences in abilities and welfare of various groups and communities. Management of these strata of society includes corporate social responsibility activities and disabled facilities.

The above contrasts with the study done by Julia et al., (2018) that delivers five themes including preserving human faith, preserving human self, preserving intellect, preserving future generations and preserving wealth. All five themes are more concerned on human wellbeing especially towards employees, customers and the community. Recurring themes cover adequate training, good working conditions, and safe working environment ensures good communication and excellent bonding among employees and protects employees" health and safety. These themes express on value creation towards business, environmental concern, energy conservation, minimizing waste, and encourage innovation among employees.

\section{Research Method}

This study reviewed previous writingon Islamic perspective for real estate management as well as referring to the revealed sources of Al-Qur'an, and Sunnah of Prophet Muhammad S.A.W. The data and information then were synthesize, themed according to suitable categories and presented in tabulation form. 


\section{Findings and Conclusion}

This study promulgates eight Islamic principles of i-CRESM practices that are points to ponder for pundits who lament the lack of research in Islamic practice for CREM as shown in Table 1. This study then changes the term sustainable Islamic principles for CREM into Islamic CRE sustainable management (i-CRESM). It then suggests further investigation into current practices by CRE managers in order to gather more relevant, recent, and accurate data.

\begin{tabular}{|c|c|}
\hline \multicolumn{2}{|l|}{$\begin{array}{l}\text { Table } 1 \\
\text { i-CRESM principles }\end{array}$} \\
\hline Sustainable Practice & Element Consideration \\
\hline $\begin{array}{l}\text { Sustainable utilization of } \\
\text { water }\end{array}$ & Efficient use of water, Water conservation \\
\hline $\begin{array}{l}\text { Organizational } \\
\text { management and good } \\
\text { governance }\end{array}$ & $\begin{array}{l}\text { Shura in decision making process, Good governance, } \\
\text { Appointing a right person in managing property, Practicing } \\
\text { principles of Islam, Good team work }\end{array}$ \\
\hline $\begin{array}{l}\text { Human satisfaction } \\
\text { (employees, occupants, } \\
\text { customer) }\end{array}$ & $\begin{array}{l}\text { Knowledge and education, Motivational and training, } \\
\text { Corporate social responsibility, Ensures good } \\
\text { communication and excellence bonding among employees, } \\
\text { Protects employees' health and safety, Cultural and ethnic } \\
\text { values }\end{array}$ \\
\hline Environment protection & $\begin{array}{l}\text { Balance of natural resources, Conserved of the environment, } \\
\text { Control use of biodiversity, Implementing environmental } \\
\text { impact assessment and mitigation }\end{array}$ \\
\hline Waste generation & Minimizing waste, Well organized \\
\hline Energy management & Energy conservation \\
\hline Innovation & Encourage innovation among employees. \\
\hline $\begin{array}{l}\text { Workspace } \\
\text { management }\end{array}$ & Good working condition, Safe working environment, \\
\hline
\end{tabular}

\section{Corresponding Author \\ Nurul Sahida Fauzi}

Department of Estate Management, Faculty of Architecture, Planning and Surveying, Universiti Teknologi MARA, Perak Branch, Seri Iskandar Campus, Seri Iskandar, 32610 Perak, Malaysia

Email: ochidsahidafauzi@gmail.com

\section{References}

Omar, A. J.,\& Heywood, C. A. (2014). Defining a corporate real estate management ' s ( CREM ) brand. Journal of Corporate Real Estate, 16(1), 60-76. http://doi.org/10.1108/JCRE-102013-0031

Sarkawi, A., Abdullah, A., \& Md. Dali, N. (2016). The concept of sustainability from the islamic perspectives. International Journal of Business, Economics and Law, 9(5), 112-116.

Darus, F., Yusoff, H., Naim, A. D. M., Zain, M., Amran, A., Fauzi, H., \& Purwanto, Y. (2013). Islamic corporate social responsibility ( $\mathrm{i}$-CSR ) framework from the perspective of maqasid al- Syariah and maslahah. Social and Environmental Accounting, 7(2), 102-112.

Fauzi, N. S., Zainuddin, A., Mohd Ali, S. N., \& Nawawi, A. H. (2016). A preliminary framework for corporate real estate sustainable management. International Building Conference 
Control, 00062. http://doi.org/10.1051/matecconf/20166600062

Fauzi, N. S., Zainuddin, A., Nawawi, A. H., \& Johari, N. (2017). The green building concept: is that a trend. Journal of Academic Research and Social Sciences, 7(11), 1440-1448. http://doi.org/10.6007/IJARBSS/v7-i11/3582

Iyad Abumoghli. (2016). Islamic Principles on Sustainable Development.

Julia, T., Kassim, S., \& Ali, E. R. A. (2018). Are the green projects in line with the maqasid shariah ? An assessment of green firms in Bangladesh. In Global Conference on Islamic Economics and Finance 2018 24th \& 25th October 2018 / Sasana Kijang, Bank Negara Malaysia, Kuala Lumpur (pp. 317-335).

Krumm, P. J. M. M., Dewulf, G., \& Jonge, H. de. (2000). The impact of evolving structures on managing corporate real estate. Journal of Corporate Real Estate, 2(1), 58-67. http://doi.org/10.1108/14630010010811211

Liow, K. H., \& Nappi-choulet, I. (2007). Corporate real estate : perspectives, evidence and issues.

Mohamad, M., \& Hussein, S. M. (2018). Stratified property management : Islamic aspect. International Journal of Asian Social Science, 8(11), 1005-1016. http://doi.org/10.18488/journal.1.2018.811.1005.1016

Musa, M. F., \& Ahmad @ Baharum, Z. (2012). Corporate Real Estate (CRE): Public Institution of Higher Learning in Malaysia. Procedia - Social and Behavioral Sciences, 36(June 2011), 273-279. http://doi.org/10.1016/j.sbspro.2012.03.030

Nappi-Choulet, I., Missonier-Piera, F., Cancel, M., Nappi-Choulet, I., Missonier-Piera, F., \& Cancel, M. (2009). Value creation and the impact of corporate real estate assets. Journal of Corporate Real Estate, 11(2), 78-90. http://doi.org/10.1108/14630010910963124

Samad, A., Hanim, M., \& Diyana, F. (2010). Towards Sustainable Buildings in Malaysia: Evaluating Malaysian Green Building Index. Journal of Sustainable Architecture and Urban Development, 45-55.

Shafie, F., Yusoff, W. Z., \& Al-Edrus, S. M. D. (2016). Islamic real estate management : review on issues and challenges in managing inheritance property in Malaysia. In 25th International Business Information Management Association Conference- Innovation Vision 2020 From Regional Development Sustainability to Global Economic GrowthIBIMA 2015 (pp. 3684-3696). International Business Information Management Association, IBIMA.

Umar, U. A., \& Khamidi, M. F. (2012). Determined the level of green building public awareness: application and strategies. In 2012 International Conference on Civil, Offshore and Environmental Engineering, Kuala Lumpur Malaysia Abstract. http://doi.org/10.13140/2.1.5095.6480

Warren-myers, G. (2012). Sustainable management of real estate : is it really sustainability? Journal of Sustainable Real Estate, 4(1), 177-197.

Ziemba, E., Ramian, T., \& Kania, K. (2015). The concept of a sustainable approach to corporate real estate management.Real Estate Management and Valuation, 23(4), 85-94. 